\title{
IMPROVING FARMER'S KNOWLEDGE ON INDIGENOUS PRACTICE OF SPRAYING PESTICIDES IN GRAPE GARDEN
}

\section{PADMA ALAPATI ${ }^{1} \&$ KHATEEJA SULTHANA SHAIK ${ }^{2}$}

${ }^{1}$ Principal Scientist, AICRP-Home Science (Clothing \& Textiles), PG \& RC, PJTSAU, Hyderabad, Telangana, India

${ }^{2}$ Senior Research Fellow, AICRP-Home Science (Clothing \& Textiles), PG \& RC, PJTSAU, Hyderabad, Telangana, India

\begin{abstract}
Usually grape orchards pruning will take place in the month of April. For this to grow well without affecting any insects, during rainy season that is, from November onwards pesticide was sprayed twice a week. And also before harvesting grape bunches are dipped into the pesticide solution, which might adversely affect the health of the sprayer. Bringing change in entire dress (Protective clothing) is a big task both in monetary and motivation in spite of adverse remarks in wellbeing. To overcome this, present study was conducted to analyze the presence of pesticide residue through Gas Chromatographic analysis on the 5 per cent starch treated Polyester Cotton 67:33, 50:50 blends, which is most commonly used material for farm workers shirting. The test was conducted against the pesticide Rogar, a dimethoate, an insecticide which is most commonly used in grape gardens, $2 \%$ concentration of which was sprayed on test sample.

Along the test samples were analyzed for the presence of pesticide residue with SHIMADZU-GC-17A type of Gas Chromatography. From the analysis, it was observed that 67:33 poly-cotton samples absorb fewer amounts of pesticide residues than 50:50 poly-cotton samples. Even though 5 per cent starch treated samples showed greater absorbency than 10 per cent starch treated sample, 5 per cent starch treated samples were selected to observe residue levels after washing with 5 per cent sodium Chloride water and 2 per cent heavy duty detergent at $120^{\circ} \mathrm{F}$ and $140^{\circ} \mathrm{F}$. Among the washings samples with 2 per cent detergent was found to be having less residues than 5 per cent sodium Chloride washed samples, where under $140^{\circ} \mathrm{F}$ removal of residue levels were greater than $120^{\circ} \mathrm{F}$.

In a view of economic conditions of the farmers, 5 per cent starch treated clothing while spraying can be suggested with 5 per cent sodium Chloride (salt) washing after pesticide spraying.

KEYWORDS: Care While Pesticide Application, Farm Workers, Protective Clothing \& Cleaning/Washing Practice
\end{abstract}

Received: Oct 05, 2017; Accepted: Oct 25, 2017; Published: Nov 09, 2017; Paper Id.: IJASRDEC201726

\section{INTRODUCTION}

India stands second in population with 1.3 billion, which accounts to 18 percent of the Global population and expected to rise to 9 billion by 2050, which further increase in the food demands. Agriculture census $2010-$ 2011 operational land holding has declined from 1.23 ha in 2005-06 to 1.16 ha in 2010-11(Analysis by Tata Strategic). So, to meet the sustainable needs of food and nutrition, great demand falls on farmer's part to produce large amounts of yield. It was also noticed that pest attacking percent in major crops has been increased from 1940s. Poor rainfalls are further adding to low or no crop production rates Hence, to overcome all the major issues associated with the farming, agrochemicals are been used it not only enhances productivity of the crop, but also protects crop from various pests (Analysis by Tata Strategic). 
Agriculture is the major occupation for Socio- Economic viability in India. Nearly 58 per cent of the rural population depends on agriculture for their livelihoods ( $6^{\text {th }}$ National Conference on Agrochemical, 2016). To make easy living, in our day to day lives, many of the pesticides are being used. Which, unfortunately are toxic and can risk health in terms of genetic damages, problems with reproductive system, etc, Analysis by Tata Strategic survey, Andhra Pradesh, Maharashtra and Punjab consumes 45 percent of pesticides in India.

With increased challenges to produce more and more food and also to reduce the poverty for the human welfare, now pesticides are playing a major role rise in the yield of the crops. Considering the human health issues, there was a restriction in dosage of pesticide usage, where few are banned. But Wilson and Tisdell, 2001 reported that developing countries are still using the banned one. FAO, 2000 have reported that 2, 00,000 people were dyeing all around the world and 3 million are poisoned with the pesticides are majorly from the developing countries.

India stands forth in agrochemical production after US, Japan and China. However, 50 Per cent of it is used by domestic market; India stands low with a consumption $0.6 \mathrm{~kg} / \mathrm{ha}$ of agrochemical, when compared with $5-7 \mathrm{~kg} / \mathrm{ha}$ in the UK and $13 \mathrm{~kg} / \mathrm{ha}$ in China. Every year world Health Organization estimates up to one million pesticides poisoning and twenty thousand death cases, where according to Pesticides Action Network Asia and Pacific, 68, 000 farm workers are poisoned daily, which is an estimate of around 25 million workers around globally (6 ${ }^{\text {th }}$ National Conference on Agrochemical, 2016).

Sayed et al. 1992 have observed ample of ECG changes in the sprayers of methmyl, acarbamate insecticide. According to Sharma et al. 1986 apart from the imbalance in the immunity, other skin related diseases along with pigmentation are adverse effects visible on pesticide applicators. Rupa et al. have studied on reproductive toxicity of couples involved in insecticide spraying at cotton fields. According to them workers involved in this activity have shown 26 per cent Abortion rate, 8.7 per cent still births, 9.2 per cent Neonatal deaths and 3 per cent congenital effects. Zaidi et al. 2000 have made observations of the formulators exposed on thyroid function in combination of pesticides, where T3 formulators have shown significant restrain and T4 have marginal decrease by 7 per cent. Another research by Karnik et al. 1993 have shown increase in serum IgG and serum IgA levels when exposed to Malathinon Cufluthrin respectively for pesticide sprayers.

Bureau of Labor Statistics have estimated that about 12.7 percent workers get injured and fall sick in different occupational workers and in specific Environment Protection Agency has ranked, chemicals as, one of the major environment health hazard that workers are exposed in their agricultural activities (EPA, 1990). According to Feldman and Maibach (1974), over a period 24 hours, different parts of human body can absorb pesticides/herbicides in different per cent rates, as shown in Figure 1. 


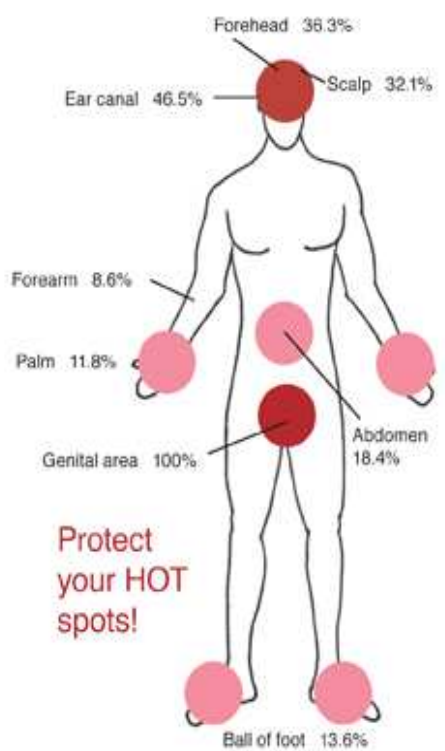

Source: Feldman and Maibach, 1974

Figure 1: Percent Absorption of pesticides/Herbicides with Different Body Parts over a Period of 24 hrs

As clothing is next to sprayer's body, there is possibility of emerging pesticide residue on to clothing while spraying, which can further be penetrated onto skin. Skin diseases occurred from occupational operations may include simple dermatitis to skin cancers. Skin hazards can be occurred due to chemical, physical, mechanical or biological agents, when exposed to the specific medium (CDC, 2013).

A garment worn by the agriculture worker is having pesticide residue, is not only affects him but also risks his family members, especially the children said by Xiao Zhou $\boldsymbol{e t .}$ al.(2007). There is a practice of sending teenage girls for spraying in grape orchards; it was provide evidence that there are possibility of miscarriage after the girl gets married. They have analyzed six types of textiles for Multi residues, effective cleaning up and positive confirmation through ultrasonic extraction of sample by determining with Gas Chromatography and Mass Spectrometry.

Any type of garment or accessory that prevents skin expose to any of hazardous agents is considered as protective clothing.

A research conducted by Rita et al 1987, has revealed there was a significant increase in the chromatid breaks of peripheral blood, as well considerable gaps was observed in the chromosomes of the pesticide exposed grape garden workers.

In the present study, pesticide residue on starch coated polyester cotton blend was analyzed in grape gardens workers clothes. The selected subject sprays pesticide twice a week from November onwards and before harvesting grape bunches is dipped into solution of pesticide.

\section{MATERIALS AND METHODS}

\section{Questionnaire Development}

Questionnaire was developed with prerequisite questions to know the baseline information of the farm families. The Information on pesticide usage was collected from 30 respondents through interview method. The commercially 
available protective clothing and other safety devices were identified and data obtained was analyzed.

\section{Fabric Selection}

Pesticide residues, after settling on fabric surface gets crystallized except $100 \%$ cotton woven fabric, which absorbs pesticide into the cotton fiber polymer structure is more, which in turn results low amounts of pesticide on the surface of the fabric (Parthiban. M. and Kumar R. M. 2007). So, it is advisable to opt for P/C blend fabric, which provides comfort to the wearer as well reduces the pesticide penetration levels in the fabric. Hence, plain woven polyester cotton $67: 33,50: 50$ blends suitable for shirting was selected for the study.

\section{Processing of Test Fabrics}

\section{Desizing the Test Fabrics}

Desizing of fabrics is done to remove any unwanted sizing material, dirt, soil etc. The nature of Desizing process usually depends up on the nature of the sizing material, soil, dirt, etc which are to be removed. The cotton fabric was boiled in a solution containing $2 \mathrm{~g}$. of sodium carbonate and $1 \mathrm{~g}$. of sodium hydroxide per 1 liter of water for 45 minutes. During the process the fabric was frequently stirred.

\section{Starch Preparation}

Starch was prepared through boiling method with 5 percent.

\section{Application of Starch}

- De-sized fabrics were dried in direct sunlight for one hour.

- The fabric to be finished was immerse in 5\% starch solution liquid and then squeezed out extra starch.

- $\quad$ Dry the fabrics in direct sunlight.

Note: unfinished fabric (control sample) was tested against treated one

\section{Selection of Pesticide}

Through reviews, pesticide pattern of usage in grape garden was Rogar, a dimethoate insecticide is one of the most commonly used insecticides and so, it was selected for the study. Rogar $30 \mathrm{EC}$ of $85 \%$ dimethionate, procured from a local shop was used for the study.

\section{Mode of Application}

Inject $2 \mathrm{mg}$ Atropine Sulphate i. v., if necessary repeat at every 15 minute, until pulse is accelerated and pupils dilate. 2PAM i. v. infusion 1-2 gm to be dissolved in 10cc distilled water giving slowly for 10-15 mins.

\section{Pesticide Application}

As per recommendations, pesticide spray solution was prepared, $2 \mathrm{ml} /$ liter of water. Spray solution was sprayed on the lab test specimens three times uniformly on the selected sample by using Ganesh sprayer. 


\section{Pesticide Residue Analysis - Estimation of Fabric Barrier Properties to Pesticide Residues}

Test samples were soaked in $5 \mathrm{~g} / \mathrm{l}$ soap solution for 24 hours. Soaked samples were squeezed, thoroughly rinsed in cold water and then shade dried. The samples were further assessed for its mechanical properties.

\section{Analysis of Pesticide Residues}

By using Gas Chromatography, the pesticide penetration in the samples was measured for quantifiable residues collected on the filter paper.

\section{Extraction of Residues}

Extraction of residue at a given time was specified by Perenich and Wilkinson (1995) and Easter et al (1983) for analyzing through Gas Chromatography. In this process the collected residue extracts were evaporated and stored at $18^{0} \mathrm{C}$ until use.

\section{Gas Chromatographic Analysis}

Gas Chromatography was commonly used for quantitative of pesticide residues. SHIMADZU-GC-17A type Gas Chromatograph with an electron capture (ECD), with a 30 meter capillary column of 0.529 mm diameter was used for the study.

\section{Calculation of Residue Accumulated on Fabric}

The total residues calculated from the total areas of standard and samples were expressed as $\mathrm{mg} / \mathrm{kg}$ in $\mathrm{ppm}$ or $1 \mathrm{~cm}^{2}$ in ppm (nano- grams per square centimeter of the fabric or $64 \mathrm{~cm}^{2}$ i.e., $8 \mathrm{~cm} \mathrm{x} 8 \mathrm{~cm}$, which is a sample size).

Final vol. of the residue solution $(5 \mathrm{ml})$

Pesticide residue in $\mathrm{ng} / \mathrm{cm}^{2}$

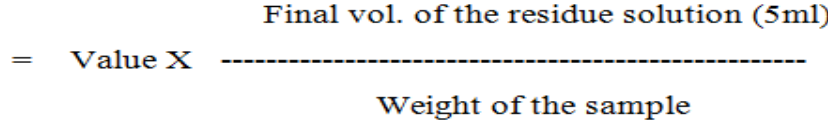

Trials at Fields

After selecting the best technique of starch application, trials were made in the fields with protective clothing equipment.

\section{RESULTS AND DISCUSSIONS}

Pre Test Information by the Respondents

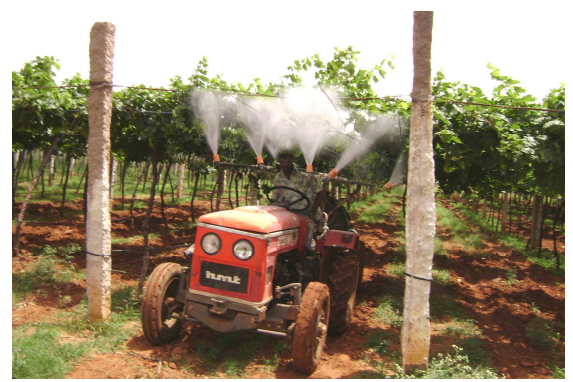

Figure 2a: Pesticide Application in Grape Garden with Tractor in Upward Direction 


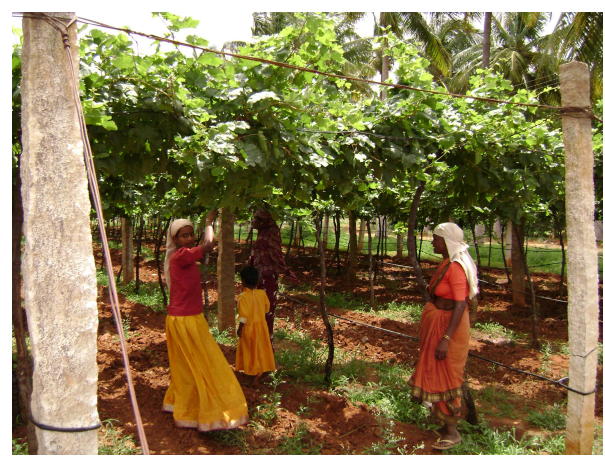

Figure 2b: Workers Working in Pesticide Sprayed Grape Garden

From the interview schedule, the respondents have revealed that they hardly cover their body while working in the fields. From the data it was also noticed, that pesticide/insecticide spraying starts from the month November with twice a week of spraying, where the grape orchards pruning starts in April.

As, the grape orchards pruning takes place during April, but to have a good crop, spraying of pesticides takes place during the November month for around two times a week

From the figure $2 \mathrm{a}$, it was clearly evident that a worker is spraying insecticide with tractor with upward direction in the grape garden is not having any sort of protection. And also women work during harvesting period, by dipping grape bunches in the pesticide solution, as shown in figure $2 \mathrm{~b}$.

This feedback from the respondents lead the study to access the presence of pesticide residue in the selected sample.

\section{Analysis of Blended Fabrics}

As any coating on any fabric increases its weight, so observations revealed that the fabric weight of the finished fabrics has increased and was greater than unfinished fabrics due to the starch finish and also shrinkage and consolidation of yarns after finishing.

Tested fabrics were analyzed with 100 per cent dimethoate (standard) using Gas Chromatography, where the residues penetrated in the sample were collected on filter paper pads and were quantified, which is expressed as ppm. Two variations in the fabric blends with Polyester and Cotton (Poly-Cotton) were depicted in Table 1. From the results it was noticed that, among the two types of fabrics, Rogar penetration rate in control sample have highest percentage in 50:50 poly-cotton with 80 percent than 67:33 poly-cotton, which showed 54 percent of penetration. Further, it can be state that, there is absorbency variation in the poly-cotton blended fabrics depend on the blend percentage. This difference in the penetration is due to the presence of cotton fabric in varied percents, which have more absorbency rate. Among the treated samples 50:50 poly-cotton with 5 per cent starch have more absorption of pesticide, followed by 67:33 poly-cotton, 67:33 and 50:50 poly-cotton with 10 percent starch.

When washed samples were tested the presence of pesticide is more for samples washed with heavy duty detergent $120^{\circ} \mathrm{F}$ than sodium Chloride water washed sample. The samples washed at $140^{\circ} \mathrm{F}$ in both sodium Chloride water and detergent has shown fewer amounts of pesticide residues than samples washed at $120^{\circ} \mathrm{F}$. 
Table 1: Presence of Pesticide Residue on the Selected Sample

\begin{tabular}{|c|l|c|}
\hline S. No & \multicolumn{1}{|c|}{ Details of the Sample } & $\begin{array}{c}\text { Presence of Pesticide } \\
\text { Residue (ppm) }\end{array}$ \\
\hline I BLEND (67:33) POLYESTER:COTTON & \\
\hline 1 & Control (Starch 5\%) & 6.13 \\
\hline 2 & Sample washed in 5\% Sodium Chloride water at $120^{\circ} \mathrm{F}$ & 1.43 \\
\hline 3 & Sample washed in 5\% sodium Chloride water at $140^{\circ} \mathrm{F}$ & 1.04 \\
\hline 4 & Sample washed in 2\% heavy duty detergent at $120^{\circ} \mathrm{F}$ & 1.64 \\
\hline 5 & Sample washed in 2\% heavy duty detergent at $140^{\circ} \mathrm{F}$ & 0.53 \\
\hline 6 & Control (Starch 10\%) & 7.58 \\
\hline 7 & Sample steeped in 5\% Sodium Chloride water at $120^{\circ} \mathrm{F}$ & 0.36 \\
\hline 8 & Sample steeped in 5\% Sodium Chloride water at $140^{\circ} \mathrm{F}$ & 0.06 \\
\hline 9 & Sample steeped in 2\% heavy duty detergent at $120^{\circ} \mathrm{F}$ & 0.06 \\
\hline 10 & Sample steeped in 2\% heavy duty detergent at $140^{\circ} \mathrm{F}$ & 0.03 \\
\hline II BLEND $(\mathbf{5 0} 50)$ POLYESTER:COTTON & 37.59 \\
\hline 11 & Control (Starch 5\%) & 0.25 \\
\hline 12 & Sample washed in 5\% Sodium Chloride water at $120^{\circ} \mathrm{F}$ & 0.07 \\
\hline 13 & Sample washed in 5\% sodium Chloride water at $140^{\circ} \mathrm{F}$ & 0.02 \\
\hline 14 & Sample washed in 2\% heavy duty detergent at $120^{\circ} \mathrm{F}$ & 0.00 \\
\hline 15 & Sample washed in 2\% heavy duty detergent at $140^{\circ} \mathrm{F}$ & 3.40 \\
\hline 16 & Control (Starch 10\%) & 0.26 \\
\hline 17 & Sample steeped in 5\% Sodium Chloride water at $120^{\circ} \mathrm{F}$ & 0.09 \\
\hline 18 & Sample steeped in 5\% Sodium Chloride water at $140^{\circ} \mathrm{F}$ & 0.13 \\
\hline 19 & Sample steeped in $\% \%$ heavy duty detergent at $120^{\circ} \mathrm{F}$ & 0.06 \\
\hline 20 & Sample steeped in $\%$ heavy duty detergent at $140^{\circ} \mathrm{F}$ & \\
\hline
\end{tabular}

Note: Total sample area $-64 \mathrm{~cm}^{2}$

Volume of solution $-5 \mathrm{ml}$

From the analysis and due to high stiffness property for the samples with 10 per cent starch, 5 per cent starch treated samples were carried out for further study. After presence of the pesticide residue was checked, its absorption by the test samples was analyzed.

Table 2: Rate of Rogar Absorption and Retention by 5 Percent Starch Treated $64 \mathrm{~cm}^{2}$ Test Fabrics (Lab Exposure) in $\mathrm{ng} / \mathrm{cm}^{2}$

\begin{tabular}{|c|c|c|c|c|c|c|}
\hline \multirow[b]{2}{*}{ Fabric code } & \multirow[b]{2}{*}{$\begin{array}{c}\text { Test } \\
\text { sample }\end{array}$} & \multicolumn{5}{|c|}{ Mean Residue Absorbed/Retained in (ng/cm²) } \\
\hline & & Control & $\begin{array}{c}5 \% \text { Sodium } \\
\text { Chloride at } \\
1^{120^{\circ} \mathrm{F}}\end{array}$ & $\begin{array}{c}5 \% \text { Sodium } \\
\text { Chloride at } \\
1^{\circ} \mathrm{F}\end{array}$ & $\begin{array}{c}2 \% \text { Heavy Duty } \\
\text { Detergent at } \\
120^{\circ} \mathrm{F}\end{array}$ & $\begin{array}{c}2 \% \text { Heavy } \\
\text { Duty } \\
\text { Detergent at } \\
140^{\circ} \mathrm{F} \\
\end{array}$ \\
\hline \multirow{2}{*}{$\begin{array}{l}\text { Blend I P/C } \\
(67: 33)\end{array}$} & UF1 & 0.478 & 0.111 & 0.081 & 0.128 & 0.041 \\
\hline & F1 & 0.592 & 0.028 & 0.004 & 0.004 . & 0.002 \\
\hline \multirow{2}{*}{$\begin{array}{l}\text { Blend II P/C } \\
(50: 50)\end{array}$} & UF2 & 2.936 & 0.019 & 0.005 & 0.001 & 0 \\
\hline & $\mathrm{F} 2$ & 0.265 & 0.020 & 0.007 & 0.010 & 0.004 \\
\hline
\end{tabular}

Note: UF1 Unfinished 67:33 (Polyester: Cotton) F1 5 \% starch finished 67:33 (Polyester: Cotton)

UF2 Unfinished 50:50 (Polyester: Cotton) F2 5 \% starch finished 50:50 (Polyester: Cotton) 


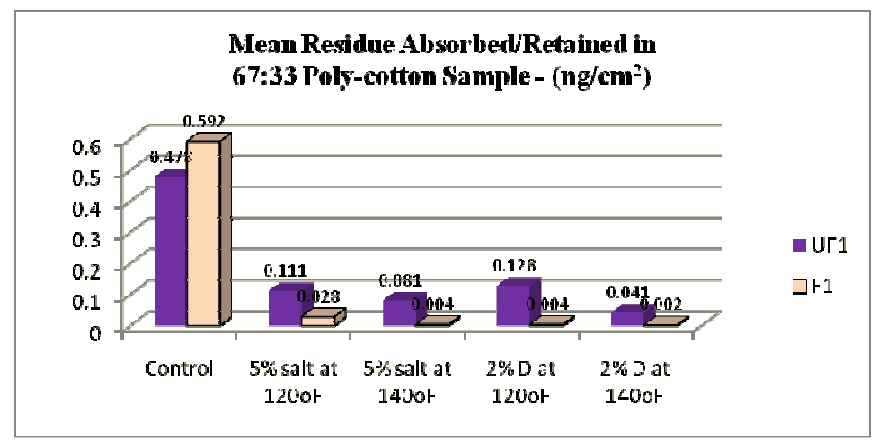

Figure 3a: Residue Present in Untreated P/C Blends

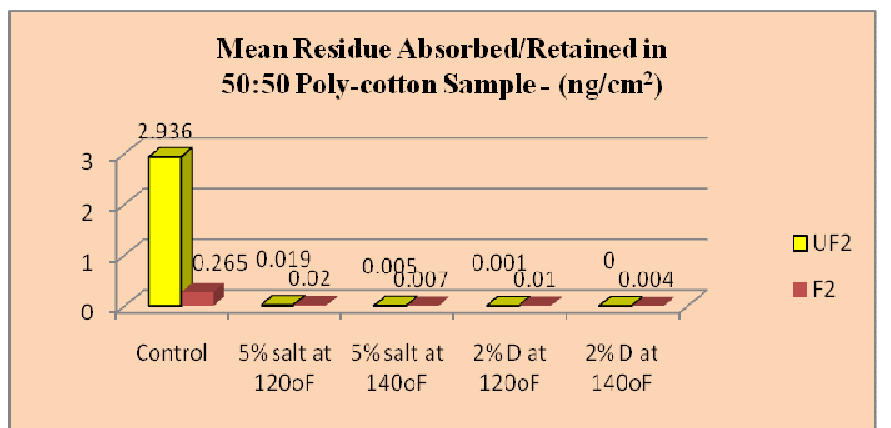

Figure 3b: Residue Present in 5 \% Starch Treated P/C Blends

The rate of Rogar absorption and retention on 67:33 and 50:50 poly-cotton samples were tabulated in Table 2 . It revealed that unfinished 50:50 P/C blends has highest residue rate compare to 67:33 P/C blend. 67:33 samples washed in 5 per cent sodium Chloride at $120^{\circ} \mathrm{F}$ and $140^{\circ} \mathrm{F}$, and $2 \%$ detergent at $120^{\circ} \mathrm{F}$ and $140^{\circ} \mathrm{F}$ has shown mean absorption of 0.111 and $0.041 \mathrm{ng} / \mathrm{cm}^{2}$ which is above the tolerance level of residue as shown in Figure 3a. Whereas 50:50 specimen washed in $5 \%$ sodium Chloride and $2 \%$ detergent at $140^{\circ} \mathrm{F}$ has exhibited 0.005 and $0.00 \mathrm{ng} / \mathrm{cm}^{2}$, as shown in figure $3 \mathrm{~b}$, which is below the tolerance level of residue.

Table 3: Residue Present after Washing of $5 \%$ Starch Treated Sample with $5 \%$ Sodium Chloride at different Temperatures

\begin{tabular}{|c|c|c|}
\hline Fabric Code & Test Samples & $\begin{array}{c}\text { Mean Residue } \\
\text { Absorbed/Retained }\left(\mathrm{ng} / \mathrm{cm}^{2}\right)\end{array}$ \\
\hline \multirow{6}{*}{$\begin{array}{l}\text { Blend I } \\
\text { P/C (67:33) }\end{array}$} & Un treated sample (Control) & 0.478 \\
\hline & $5 \%$ sodium Chloride at $120^{\circ} \mathrm{F}$ & 0.111 \\
\hline & $5 \%$ sodium Chloride at $140^{\circ} \mathrm{F}$ & 0.081 \\
\hline & Starch treated sample Control & 0.592 \\
\hline & $\begin{array}{l}\text { Starch treated sample } 5 \% \\
\text { sodium Chloride at } 120^{\circ} \mathrm{F}\end{array}$ & 0.028 \\
\hline & $\begin{array}{l}\text { Starch treated sample } 5 \% \\
\text { sodium Chloride at } 140^{\circ} \mathrm{F}\end{array}$ & 0.004 \\
\hline \multirow{6}{*}{$\begin{array}{l}\text { Blend II } \\
\text { P/C (50:50) }\end{array}$} & Un treated sample (Control) & 2.936 \\
\hline & $5 \%$ sodium Chloride at $120^{\circ} \mathrm{F}$ & 0.019 \\
\hline & $5 \%$ sodium Chloride at $140^{\circ} \mathrm{F}$ & 0.005 \\
\hline & Starch treated sample Control & 0.265 \\
\hline & $\begin{array}{l}\text { Starch treated sample } 5 \% \\
\text { sodium Chloride at } 120^{\circ} \mathrm{F}\end{array}$ & 0.020 \\
\hline & $\begin{array}{l}\text { Starch treated sample } 5 \% \\
\text { sodium Chloride at } 140^{\circ} \mathrm{F}\end{array}$ & 0.007 \\
\hline
\end{tabular}




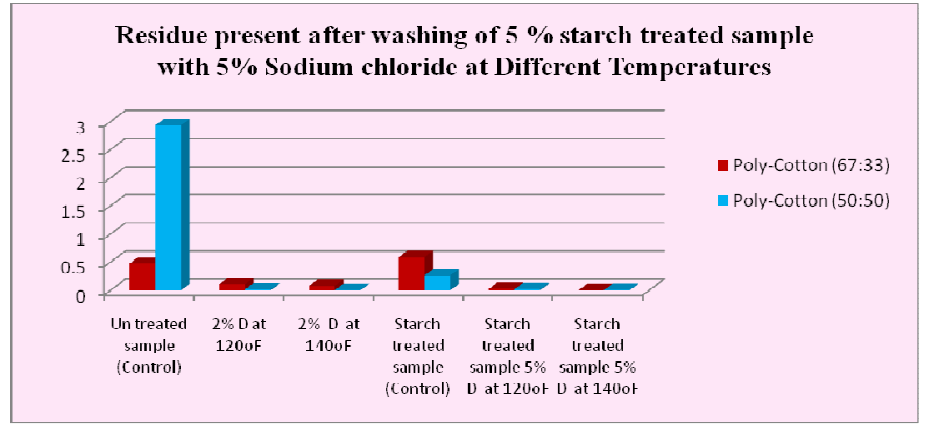

Figure 4: Residue Present After Washing of $5 \%$ Starch Treated Sample with $5 \%$ Sodium Chloride at different Temperatures

The samples without starch barrier have observed maximum of pesticide residue for 67:33 and 50:50 poly-cotton blend fabrics with $0.478 \mathrm{ng} / \mathrm{cm}^{2}$ and $2.936 \mathrm{ng} / \mathrm{cm}^{2}$ respectively. 5 per cent starch treated 67:33 Poly-Cotton fabric has shown peak level of $0.592 \mathrm{ng} / \mathrm{cm}^{2}$ residue, where 50:50 Poly-Cotton fabric has showed $0.265 \mathrm{ng} / \mathrm{cm}^{2}$, which is low when compared to 67:33 Poly-Cotton fabric, as shown in figure 4. Whereas, after washing with 5 Per cent sodium Chloride solution there was a reduced peak levels were observed for both type of fabric blends. But, washing at $140^{\circ} \mathrm{F}$ have shown better results than washing at $120^{\circ} \mathrm{F}$, see Table 3 .

When observed, the application of the pesticides/insecticides in the fields, farmers use more than the recommended doses. If used in recommended doses and applied on seeds, soil, irrigation water and crops it prevents damage from pests, weeds and diseases (Analysis by Tata Strategic).

Table 4: Residue Present after Washing of $5 \%$ Starch Treated Sample with $2 \%$ Detergent at different Temperature

\begin{tabular}{|c|c|c|}
\hline $\begin{array}{l}\text { Fabric } \\
\text { Code }\end{array}$ & Test Fabrics & $\begin{array}{c}\text { Mean Residue Absorbed/ } \\
\text { Retained }\left(\mathrm{ng} / \mathrm{cm}^{2}\right)\end{array}$ \\
\hline \multirow{6}{*}{$\begin{array}{l}\text { Poly-Cotton } \\
(67: 33)\end{array}$} & Un treated sample (Control) & 0.478 \\
\hline & $2 \%$ Detergent at $120^{\circ} \mathrm{F}$ & 0.128 \\
\hline & $2 \%$ Detergent at $140^{\circ} \mathrm{F}$ & 0.041 \\
\hline & Starch treated sample Control & 0.592 \\
\hline & Starch treated sample $5 \%$ Detergent at $120^{\circ} \mathrm{F}$ & 0.004 \\
\hline & Starch treated sample $5 \%$ Detergent at $140^{\circ} \mathrm{F}$ & 0.002 \\
\hline \multirow{6}{*}{$\begin{array}{l}\text { Poly-Cotton } \\
(\mathbf{5 0 : 5 0 )}\end{array}$} & Un treated sample (Control) & 2.936 \\
\hline & $2 \%$ Detergent at $120^{\circ} \mathrm{F}$ & 0.001 \\
\hline & $2 \%$ Detergent at $140^{\circ} \mathrm{F}$ & 0 \\
\hline & Starch treated sample Control & 0.265 \\
\hline & Starch treated sample $2 \%$ Detergent at $120^{\circ} \mathrm{F}$ & 0.01 \\
\hline & Starch treated sample $2 \%$ Detergent at $140^{\circ} \mathrm{F}$ & 0.004 \\
\hline
\end{tabular}

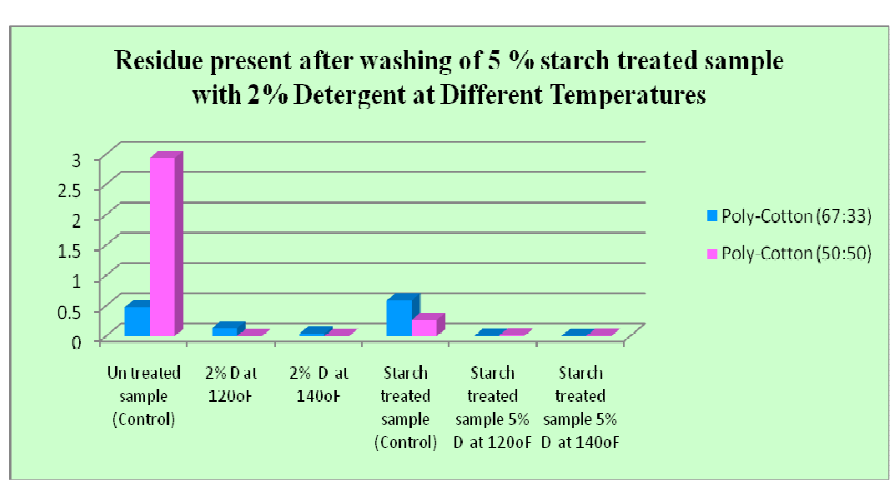




\section{Figure 5: Residue Present After Washing of $5 \%$ Starch Treated Sample with $2 \%$ Detergent at different Temperature}

From the Table 4 and Figure 5, Samples washed with 2 per cent detergent were analyzed for pesticide residue. Samples washed with detergent have shown a vast reduction of pesticide residue. With the use of temperatures residue levels for few samples have shown almost negligible.

\section{Trials in the Fields}

Trials were conducted in the fields, where the respondents have showed little interest in the starch coated protective clothing developed in lab. As per the feedback, the respondents are feeling suffocation and nausea with the commercial protective clothing. When given the same starch coating to their regularly used poly-cotton blend shirts, the adaptability was very good and effective.

In order to overcome the hazardous affects of pesticides or insecticides residue during spraying, it is advisable to protect and safeguard oneself completely before spraying process, as shown in Figure 6b., than without protection as in Figure 6a.

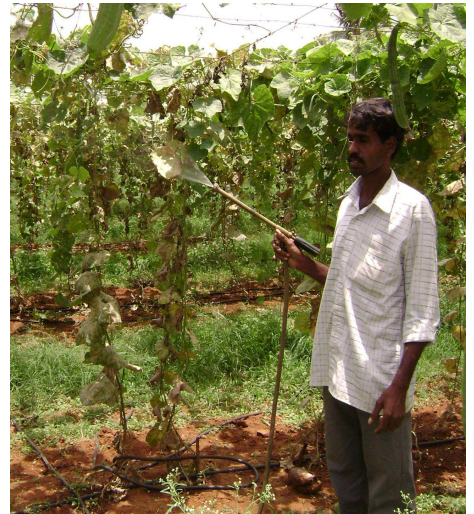

Figure 6a: Existing Practice while Pesticide Application

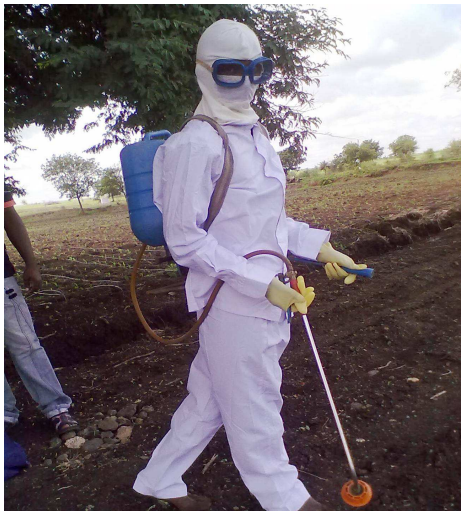

Figure 6b. Suggested Protection while Pesticide Application

\section{Few Suggestions to Pesticide Sprayers}

- At the end of one's work day, take off the work clothes, shower, and put on clean clothes.

- Use a separate container to place work clothes contaminated by the pesticides until washed.

- Do not ride home wearing pesticides clothes, it can contaminate the vehicle as well home and the environment.

- Even though sprayer is fully covered, his work clothes are going to absorb traces of pesticides.

- Do not in contact with others, until cleaning, washing and bathing.

- Be sure to keep the contaminated clothes away from the children at home.

- If possible leave the pesticide contaminated clothes at work place and launder there at safe place.

\section{CONCLUSIONS}

From the present study it was observed that, if a barrier or coating is given on the work clothes of pesticide sprayers, it can reduce the hazardous effects on the health of the workers. 
Even after applying 5 per cent starch to both types of fabrics, 50:50 poly-cotton samples has retained more pesticide residue than 67:33 poly-cotton samples. From this observation, it was suggested to select 67:33 Poly-Cotton fabrics on 50:50 Poly-Cotton fabrics.

By washing the samples with 5 per cent sodium Chloride and 2 per cent detergent has shown tremendous decrease in the residue level. When compared with respective treatments of 5 percent sodium Chloride washed samples, 2 per cent detergent samples has shown lower levels of pesticide residue. It suggested the worker to select 2 per cent detergent to wash the pesticide polluted clothing after spraying. But, considering the economic viability 5 per cent sodium Chloride wash was also recommended.

As 10 per cent starch gives thicker layer than 5 per cent starch treated samples, which in turn influences the rate of pesticide absorption. But, considering the stiffness property, 5 per cent starch treatment is more advisable.

\section{ACKNOWLEDGMENT}

It is privilege for the authors to thank ICAR, New Delhi for providing financial assistance under All India coordinated research project on Home Science through CIWA, Bhubaneswar for successful carrying out of this project.

\section{REFERENCES}

1. Analysis by Tata Strategic. $6^{\text {th }}$ National Conference on Agrochemicals. A report on Indian Agrochemical Industry. 2016. Next Generation Indian Agriculture - Role of Crop Protections Solutions. Federation of Indian Chambers of Commerce and Industry (FICCI) in association with the Department of Agriculture Cooperation \& Farmers Welfare and the Department of Chemicals and Petrochemicals (C\&PC). Knowledge and Strategic Partner- Tata Strategic Management Group. New Delhi. (http://www.tsmg.com/insights/chemical-ins.html)

2. CDC 24/7: Saving lives, Protecting People.2012. Skin Exposures and Effects. NIOSH Workplace Safety and Health Topic. The National Institute for Occupational Safety and Health. Centers for Disease Control and Prevention. (http://www.cdc.gov/niosh/topics/skin/)

3. Easter, M. C., Gibson, D. M. \& Ward, F. B. 1983. The induction and location of trimethylamine Noxide reductase in Shewanella sp. NCMB 400. Journal of General Microbiology 129, 3689-3696

4. Environmental Protection Agency (EPA). 1990. - Reducing Risk: Setting Priorities and Strategies for Environmental Protection. September 1990 report of the Science Advisory Board.

5. Eric Hansen and Martin Donohoe. 2003. Health Issues of Migrant and Seasonal Farm workers. Journal of Health Care for the Poor and Underserved. Vol: 14(2): 153-164.

6. FAO. 2000. Project Concept Paper. HEALTH: Health in Ecological Agricultural Learning. Prepared by the FAO programme for Community IPM in Asia. Food and Agricultural Organization of United nations, Rome. http://www.fao.org/nars/partners/2nrm/proposal/9-2-6.doc.

7. Feldman and Maibach, 1974, Percutaneous Penetration of Some Pesticides and Herbicides in Man. Toxicology and applied Pharmacology, 28:399-404

8. Karnik, S. S., Ridge, K. D., Bhattacharya, S., and Khorana, G. H. 1993. Proc. Natl. Acad. Sci. U. S. A. 90, 40-44

9. Parthiban. M. and Kumar R. M. 2007. Application of Protective Clothing in Textiles. Indian Textile Journal. 117(9):83-86.

10. Perenich, T.A. \& Wilkinson, R.P. (1995). A comparative analysis of methodologies used to extract pesticide residues from 
fabrics. 41. 55-61.

https://www.researchgate.net/publication/295554363_A_comparative_analysis_of_methodologies_used_to_extract_pesticide_resid ues from fabrics

11. Rita P., Reddy P. P., and Reddy S. V. 1987. Monitoring of workers occupationally exposed to pesticides in grape gardens of Anthra Pradesh. Environ. Res. 44: 1-7.

12. Rupa D. S., Reddy P. P and Reddy O. S. 1991. Reproductive Performance in Population Exposed to Pesticides in Cotton Fields in India. Envron. Res. 55: 123-128.

13. Sayed H. N., Sadhu H. G., Bhatnagar V. K., Dewan A., Venkaiah K. and Kashyap S. K. 1992. Cardia Toxicity following short term Exposure to Methomyl in Spray - men and rabbits. Hum. Exp. Toxicol. 11: 93-95.

14. Sharma R. p., Bhatnagar V. K., Saigal S., Gupta M. M., Bansal G. and Malviya A. N. 1986. Skin Diseases in Workers Handling Pesticides. Environ. Ecol. 4: 175-177.

15. Wilson C. and Tisdell C. 2001. Why Farmers continue to use Pesticides despite Environmental, Health and Sustinability Costs. Ecol. Econ. 39:449-462.

16. Xiao Zhou, Mingtai Wang, Zhe Sun, Aijun Li, Liming Xu, Jun Mu, and Lijun Lu. 2007. Multiresidue Determination of 77 Pesticides in Textiles by Gas Chromatography-Mass Spectrometry. Journal of Chromatographic Science, Vol: 45(8): $375-$ 378.

17. Zaidi S. S. A., Bhatnagar V. K., Gandhi S. J., Shah M. P., Kulkarni P. K., and Sayed H. N. 2000. Assessment of Thyroid functions in Pesticide Formulators. Hum. Exp. Toxicol. 19:497-500.

18. (https://en.wikipedia.org/wiki/Personal_protective_equipmentt 